\title{
World police for world peace: British internationalism and the threat of a knock-out blow from the air, 1919-1945
}

\author{
Brett A. Holman
}

[This version of the paper was accepted in October 2009. It has undergone peer review. The final, definitive version of this paper has been published in War in History, volume 17, issue 3, July 2010 by SAGE Publications Ltd, All rights reserved. (C) Brett Holman]

\begin{abstract}
This paper argues that the remarkably widespread enthusiasm in Britain after 1918 for an international air force was due to a confluence of two factors: the long-standing liberal belief that international law could prevent war, and the emergence of a new theory of warfare which claimed that the bomber was a weapon which could not be defended against. The origins of the international air force concept in the 1920s, its apogee in the 1930s, and its decline (and revival) in the Second World War are examined, showing that its fortunes rose and fell with internationalism and the knock-out blow.
\end{abstract}

A Introduction

On the eve of Armistice Day, 1932, Stanley Baldwin gave one of the most famous 
parliamentary speeches of his long political career. Responding to a Labour motion calling on the National Government to give its support to the 'immediate, universal, and substantial reduction of armaments on the basis of equality of status for all nations', the Lord President of the Council (and former Conservative prime minister) admitted that the world suffered from 'a sense of fear', for which nothing was more responsible than 'the fear of the air', the fear of aerial bombardment. He predicted that

in the next war you will find that any town which is within reach of an aerodrome can be bombed within the first five minutes of war from the air, to an extent which was inconceivable in the last war, and the question will be whose moral will be shattered quickest by that preliminary bombing?

Baldwin argued that the sky was so vast that there no possibility of building enough fighter aircraft to give a good chance of intercepting enemy air raids, meaning that 'The bomber will always get through'. Therefore, 'The only defence is in offence, which means that you have to kill more women and children more quickly than the enemy if you want to save yourselves'. He did not believe that universal disarmament could prevent a catastrophic aerial bombardment of Britain's cities. But neither did he propose increasing the size of the RAF's bomber force to provide an effective deterrent. Instead Baldwin spoke favourably, if not very hopefully, of 'the abolition of the air forces of the world and the international control of civil aviation'. ${ }^{1}$

While Baldwin's speech is well known, his advocacy in it of the international control of 
civil aviation is not. His overture was a small part of a much wider movement towards an internationalist solution to the problem of the 'knock-out blow', the problem which Baldwin had outlined in his speech to the House of Commons. Fear of the knock-out blow was nowhere more acute than in Britain itself, which had been bombed extensively, although not intensively, during the First World War. ${ }^{2}$ After 1918, airpower theorists such as Brigadier-General P.R.C. Groves, Britain's former representative on aviation questions at the League of Nations in Geneva, helped popularize a new theory of warfare which had its origins in a reaction against the bloody stalemate on the Western Front. These writers held that the quickest route to victory was not through the clash of armies but the bombing enemy civilians from the air, which would destroy their morale and thereby force their government to surrender. ${ }^{3}$ Such a knock-out blow against Britain could be effected by a sudden, devastating attack on London and other cities, carried out by hundreds or thousands of enemy bombers. A British collapse could come within days or weeks; civilian casualties might number in the millions. Groves and other, mostly conservative, writers believed that the RAF should therefore be built to parity with the largest air force within striking distance on Britain, to act as a deterrent. ${ }^{4}$ On the left, which also widely accepted the theory of the knock-out blow, disarmament was far more popular. ${ }^{5}$ But there was a third way between parity and disarmament, and one which had support from surprising quarters: the internationalization of aviation. It combined the growing conviction of liberal internationalists, during and after the war, that new institutional frameworks were needed to prevent its recurrence, with the widespread perception that airpower was now, or soon would be, the ultimate force in international affairs. ${ }^{6}$ It encompassed two distinct, but usually linked, proposals: the 
internationalisation of civil aviation, and the internationalisation of military aviation, usually referred to as the international air force.

The international air force concept can be considered a form of collective security, except that it involved a pooling of sovereignty, and consequently the relinquishing of command over at least a portion, and perhaps all, of a national air force to a supranational organization, probably the League of Nations. Indeed, it was sometimes welcomed - or feared - as the beginnings of a European or world state. ${ }^{7}$ It was often invoked as a step in the process of total disarmament, alongside the establishment of an international tribunal for the impartial adjudication of disputes. The international air force was sometimes termed a police force, since it was meant to enforce international law fairly and impartially, in analogous fashion to a civil police force. ${ }^{8}$ For a time in the late 1920 s and early 1930s, it was a possibility considered seriously by British politicians concerned about the preservation of Europe's precarious stability, at least by their own account; and one which attracted much interest from peace-minded intellectuals, activists and ordinary people of all political persuasions.

The international control of aviation was the most radical response to the threat of the knock-out blow. Although it never actually took place, the frequency and intensity of the calls for such an unprecedented infringement of national sovereignty are evidence that powerful mentalities were at work in Britain between the wars. Particularly evident were two distinct and dissimilar intellectual outcomes of the First World War: the widespread enthusiasm for collective security and the increasing fear of war. ${ }^{9}$ According to its 
advocates, an international air force, organized on a permanent basis and always ready for action, would have reconciled and united these mentalities: the power of the aeroplane would be used to preserve peace, or at least enforce it, against any aggressor. But as a compromise between the beliefs of those who denied the legitimacy of force in international relations and those who accepted that violence could and should be used to defend the international order, the calls for international air force also marked a point of fracture in the apparently powerful British peace movement. For these reasons, a closer examination of this failed attempt to harness the bomber in the service of internationalism is worth undertaking. ${ }^{10}$

\section{A Transportation is civilization}

Proposals for some form of international military or naval force to preserve or enforce peace long predated the coming of aviation. ${ }^{11}$ Early aircraft were not sufficiently powerful for such a role, but their potential range and speed prompted some fictional speculation about international air forces. A science-fictional novel published in 1910, J.L.J. Carter's Peggy the Aeronaut, included a fictitious newspaper article which supposed that the nations would one day see that 'the piling up of aerial fleet against aerial fleet was just as mad a business as was the old-time race in the building of warships', leading to a consensus for an 'international parliament' with 'order preserved by some system of police, just as effectively as empires and nations, counties and cities, rural districts and parishes, are regulated to-day'. ${ }^{12}$ However, the aerial nature of this police force is no more than implied by the stated superiority of aircraft over older 
weapons in Carter's plot. It is much clearer in a short story published by Rudyard Kipling in 1912, 'As easy as A.B.C.' This is set in 2150, when the world is ruled by an authoritarian Aerial Board of Control with a monopoly on aviation and hence force:

'Transportation is Civilisation. Democracy is Disease'. ${ }^{13}$ Kipling's story was widely read. But during the First World War, most proponents of an international police force thought in terms of armies and navies, not air forces. ${ }^{14}$ This is not surprising, since aircraft played only a relatively minor role in determining the outcome of the war. ${ }^{15}$

\section{A Fixing the Covenant}

The idea of an international air force began to receive more serious consideration shortly after the First World War. This corresponded with the rise to prominence of the knockout blow theory. Although first elaborated by the aviation pioneer Claude GrahameWhite and journalist Harry Harper in 1916, the knock-out blow was really popularized by Groves in an influential series of articles published in The Times in March $1922 .{ }^{16} \mathrm{He}$ described how the next war would begin (and end) in sobering terms:

Each side will at once strike at the heart and nerve centres of its opponent; at his dockyards, arsenals, munitions factories, mobilization centres, and at those nerve ganglia of national moral - the great cities. The air raids of the past are no guide as to the nature of future aerial attack, or even of that which could be delivered to-day $[\ldots]$ There is no need to enlarge upon the results of aerial bombardments with high explosive, incendiary, and poison gas, delivered by thousands of bombers. ${ }^{17}$ 
Groves's articles, which also revealed how just how small the RAF was when compared with the French air force, caused quite a stir and created the widespread perception that Britain's cities were in danger of destruction from the air, and that something needed to be done about it. Groves wanted the government to subsidize British civil aviation in peacetime in order to provide the basis of a huge bomber fleet in wartime, as opposed to an expensive expansion of the regular RAF. ${ }^{18}$ It was not long, however, before the internationalisation of airpower appeared as an alternative to parity in armaments.

The very end of the war had witnessed the birth of an Inter-Allied Independent Force, composed of bomber squadrons from Britain, France, Italy and the United States. It was formed too late to see action, but did set a precedent of sorts for an international air force. ${ }^{19}$ There was some discussion before and during the peace negotiations at Paris in 1919 of giving the proposed League of Nations its own military arm, but nothing came of them. ${ }^{20}$ Instead, the Covenant of the League provided for joint military action with participation at the discretion of each member state, a mechanism of limited usefulness and one which was never used. Nor was British parliamentary opinion much interested in the possibility of an international air force in the immediate postwar period. ${ }^{21}$ But the idea began to gain ground. One stepping stone was proposed by Lord Robert Cecil, a Conservative politician who was intimately involved in the creation of the League. In 1922, while acting as South Africa's representative to the General Assembly of the League, he proposed a mutual guarantee of defence between signatories to be enforced by each nation's air force. This would provide for the 'ear-marking [of] considerable 
numbers of airoplanes [sic] from all the Members of the league to be ready to crush anyone who ventured on a sudden air attack' ${ }^{22}$ Writing in The Times, Groves declared Cecil's proposal the 'most promising' suggestion made yet by any League member, steering a middle course as it did between disarmament and a League military force. ${ }^{23}$ This might seem surprising, but in fact Groves himself - recently retired as British Air Representative on the Permanent Advisory Committee on Armaments at the League of Nations - had suggested something similar at the first General Assembly in 1920, to no avail: a failure he later blamed for the emasculation of the League. ${ }^{24}$

Interest in an international air force increased in the late 1920s, following the failure of two major diplomatic initiatives to give the League teeth, the Draft Treaty of Mutual Assistance in 1923 and the Geneva Protocol in $1924 .{ }^{25}$ Winston Churchill, for one, speculated in the final volume of his widely-read history of the First World War that an opportunity had been missed when the Covenant had been drawn up to include the principle that 'the power of the air should be reserved to the League of Nations for the purpose of maintaining world peace against aggression ${ }^{26}$ More detailed schemes were already being circulated, however. In 1927, Philip Noel Baker, then a professor of international relations at the University of London, proposed a system of mutual guarantees based upon contingents from national air forces, much like Cecil's system, but with the addition of 'skeleton bases and depôts for the use of foreign air units which might lend their help' to nations under threat. ${ }^{27}$ This was a step in the direction of a formal organization with its own aerodromes and personnel. A more fully-fledged international air force proposal - perhaps the first - appeared that same year in a book by 
William McDougall, an academic psychologist who was an influential theorist of the behaviour of crowds in disasters. ${ }^{28}$ He maintained that, given the disbanding of national air forces, 'a comparatively small international air-force, stationed at a few well-chosen centres, could serve effectively as the International Police which is required to render International Law and to assure International Justice'. Possessing 'force overwhelming and shattering', such an organization could 'guarantee all nations against sudden aggression', and also 'protect civilization against the attacks of barbaric hordes'.

The institution of such an international air-force might, then, well lead to general abandonment of national armaments, and might initiate an era of universal peace. For, given the condition that the International air-force were the only one in existence, resistance to it would be hopeless, and no nation would attempt it. ${ }^{29}$

In McDougall's view, the international air force would be used to maintain the status quo while disputes between nations were arbitrated by the International Court of Justice; a breach of the peace by any party would lead the Court to 'immediately direct against it sufficient police-force to secure its submission'. ${ }^{30}$

The philanthropist and former Liberal MP David Davies (Lord Davies from 1932), one of the founders of the League of Nations Union (LNU), soon became Britain's most persistent advocate of an international police force. ${ }^{31}$ His book, The Problem of the Twentieth Century, published in 1930 and revised in 1934, was the standard text on the subject. ${ }^{32}$ Although there was some sentiment within the LNU for giving the League its 
own military arm, in 1932 he decided to set up an entirely new organization for the promotion of an international police force, the New Commonwealth. ${ }^{33}$ In The Problem of the Twentieth Century, Davies advised that although 'in course of time the chariots of the air will play a decisive part in the service of the international authority', they were not yet ready for this role and so an international police force should not, in the first instance, rely upon airpower alone. ${ }^{34}$ But in practice the publications of the New Commonwealth focused almost exclusively on the international air force, including a comprehensive scheme presented to the International Congress in Defence of Peace at Brussels in $1934 .{ }^{35}$ In Force and the Future, for example, also published in 1934, Davies claimed that the power of the bomber was already irresistible: 'To-day, however, a nation with undisputed mastery of the air could annihilate with ease every living person in a hostile country with the minimum of exertion and loss to itself,${ }^{36}$ Although he rejected reprisal bombing as an effective deterrent, like Noel Baker Davies hoped that in its internationalised form the aeroplane was itself the solution to the dilemma it had posed. He laid down five principles which should underpin any international police force. First, that it should be superior in both numbers and armament to any possible enemy, including rogue member states or states from outside the League, such as the United States and the Soviet Union. ${ }^{37}$ Second, that it would have no power to intervene in the domestic affairs of any League state. ${ }^{38}$ Third, that protection would only be a League states which contributed to the force, to avoid the danger of moral hazard. ${ }^{39}$ Fourth, that there must be unity of command over the force, exercised by the League. ${ }^{40}$ And fifth, that the force should 'embrace all the instruments of coercion, military, naval and aerial, within its circle', to ensure that all nations played their part in both disarmament and policing, and that one country was not 
forced to give up its large navy while another kept its large army. ${ }^{41}$ This was to be truly collective security.

\section{A High tide}

The idea of an international air force spread widely in the early 1930s. The time seemed right to reopen the question of a League police force, with the spirit of Locarno calming international relations, the worldwide economic crisis suppressing military spending, and the Disarmament Conference providing a fresh opportunity for debate and negotiation. A torrent of ideas and proposals poured forth. Several governments, including those of France and Spain, submitted plans for an international air force or the internationalisation of civil aviation to the Disamament Conference in 1932 and $1933 .{ }^{42}$ Variants of the international air force concept featured in a number of science fiction novels, including H.G. Wells' The Shape of Things to Come, Michael Arlen's Man's Mortality and Brian Tunstall's Eagles Restrained. ${ }^{43}$

The international air force idea was almost a panacea for many on the left, as well as for the still-numerous supporters of the Liberal Party. It was favoured by prominent left-wing and liberal internationalists such as Norman Angell and Noel Baker. ${ }^{44}$ The National Liberal Federation proposed 'international regulation or control over all civil aviation, so as to prevent the sudden transformation of civil into military aircraft', and thought that an international police force may one day be 'desirable'. The Women's National Liberal Foundation was even bolder in its demand for an international air force. ${ }^{45}$ Similarly, the 
Next Five Years Group, a Liberal-dominated centrist group, urged the government to 'consider without prejudice' the formation of 'an international air force with the limited function of preventing misuse of civil aircraft ${ }^{46}$ Labour went further, promising in its 1935 manifesto to 'propose to other nations the complete abolition of all national air forces, the effective international control of civil aviation and the creation of an international air police force ${ }^{47}$ Jonathan Griffin, editor of Essential News and author of Britain's Air Policy, disclaimed any political affiliation, but was so incensed at the National Government's refusal to commit to the internationalisation of aviation - while simultaneously and, in his opinion, falsely claiming that other nations would not accept it - that he called on his readers to make every effort 'to get a Government of the Left in Great Britain, such that it will use all the prestige of Great Britain to create permanent peace in the air'. ${ }^{48}$ The economist G.D.H. Cole's call for a popular front included support for 'the creation of an international armed force - especially an air force - internationally recruited and under international command' (although, ever the Fabian, he doubted that it was 'practicable at the initial stage'). ${ }^{49}$ One of the most vocal supporters of the international air force in the late 1930s was L.E.O. Charlton, a retired air commodore who was also a socialist, and who sincerely believed that there was no greater threat to the working class than the knock-out blow. ${ }^{50}$

But the international air force was not merely a liberal or left-wing cause. Indeed, among the earliest proponents of an international air force were prominent conservatives such as Cecil and Churchill, while Groves, another early (if lukewarm) supporter, also had rightwing politics. ${ }^{51}$ Churchill became president of the British section of the New 
Commonwealth in $1936 .{ }^{52}$ The Spectator, an influential conservative weekly, discussed the international air force concept favourably on a number of occasions. ${ }^{53}$ The nonpartisan LNU formally adopted a version of the international air force into its programme in November $1934 .{ }^{54}$ And MPs from all the major parties introduced bills in Parliament supporting the internationalisation of aviation. ${ }^{55}$ Measured in terms of the interest taken in the international air force across the political spectrum, its prospects had never seemed better.

A The International Air Police Force and World Airways

A number of different plans for an international air force were put forward in Britain during the 1930s. The most influential, perhaps, was that published by Noel Baker in $1934 .{ }^{56}$ In a contribution to a collection of antiwar essays entitled Challenge to Death, he proposed the formation of an International Air Police Force (IAPF): 'one single homogenous corps, recruited, organised, equipped, armed and paid by an international authority, the League of Nations, and owing allegiance to the League alone'. ${ }^{57}$ In the first instance, the IAPF would confine its operations to Europe, where the danger of bombing was acute ${ }^{58}$ Its chief of staff would have to be from one of the smaller nations, perhaps Sweden or the Netherlands, as the major powers would not trust somebody from one of their potential rivals. The personnel would, of course, be recruited from all over Europe, probably on a quota basis, with excellent salaries and pensions to attract 'the finest type of men'. ${ }^{59}$ The question of where the IAPF should be based was more complicated. Noel Baker's suggestion was that it 'must be ready to take action in any part of Europe', and 
therefore needed a number of permanent aerodromes across the continent:

These bases must be situated in the smaller countries, where there will be no fear that a powerful government will seize them and use the League's material for aggression against a weaker State. Sweden, Spain, perhaps Austria, perhaps Switzerland and Greece seem by their geographical position to be the countries where bases could most usefully be placed. ${ }^{60}$

The aerodromes needed to be able to withstand a possible knock-out blow from an aggressor's converted civilian aircraft, as far as was possible: bomb-proof and gas-proof underground hangars, with large reserves of parts, fuel and ammunition, defended by anti-aircraft guns and searchlights. ${ }^{61}$ The IAPF would also need mobile ground support and air defence units, so that it could redeploy across Europe as needed. ${ }^{62}$ As for its aircraft, they needed to be of the highest quality:

its machines must be faster, have a higher ceiling, a better climb, a longer range, fewer 'blind spots,' a greater power of swift manœuvre; they must be better armed, and, if it be consistent with these other qualities, better protected against attack especially machine-gun fire - than the most efficient civil aircraft which they may have to meet. ${ }^{63}$

In order to minimize the risk of an aggressor destroying all or most of the IAPF's sources of supply, it should obtain its aircraft - built to its own specifications - from countries 
spread around the world. ${ }^{64}$ All of this would be expensive, but still cheaper overall than the present competition in armaments. Noel Baker suggested that a thousand aircraft would suffice for Europe, at least at first; this would cost no more than $£ 20$ million per annum - a fifth of the total European expenditure on national air forces. The cost would be apportioned among member states according to the same formula used to calculate contributions to the League's budget, the barême. ${ }^{65}$

Noel Baker also considered the functions of the proposed IAPF. In peacetime, detachments would be stationed at aerodromes across Europe, to keep watch for the possible conversion of civilian aircraft to military use. Such detachments 'might thus constitute a serious guarantee against aggression, ${ }^{66}$ In a period of international crisis, when a major war threatened to erupt, the IAPF could be used to monitor any troop movements, ferry in international observers and negotiators, or enforce a demilitarized zone. ${ }^{67}$ It might even deter any aggression by a simple show of force: 'its mere presence on the scene when a serious dispute arose, would in itself be a powerful guarantee that war would not occur ${ }^{98}$ But if war did come, then the IAPF would be required to fight. Noel Baker was adamant that it should only provide air defence, and not engage in counter-bombing:

The bombing of civil populations, the destruction of great cities, however grave the provocation of the aggressor, could only embitter the quarrel between his people and the outside world. The International Air Police Force should consist, therefore, of high-performance fighting or 'interceptor' craft, and not of bombing planes. ${ }^{69}$ 
It may seem counter-intuitive that Noel Baker expected an international air force to be effective without the power of the knock-out blow at its disposal, especially since he shared the widespread disdain for the possibility of air defence. ${ }^{70}$ The reason for this, as he was at pains to point out, was that after the general disbandment of national air forces the only aircraft it might possibly have to fight would have been converted from civilian use, which would be greatly inferior to the specialized machines of the international air force. ${ }^{71}$ But if the ersatz bombers managed to get through after all, and the aggressor continued his air bombardments in spite of every warning that reprisals would be made, then no doubt the League of Nations would decide to mobilise the civil aircraft of the outside world to bombard his cities until he stopped. This would be a desperate measure, undertaken in the last resort when all else had failed to stop the massacre of the innocent citizens of the victim State. ${ }^{72}$

The IAPF's only role in this case would be to escort the League's converted civilian aircraft. Noel Baker doubted that it would come to this: the international air force would itself either deter attack altogether, or destroy any aerodromes used to launch an attack, thus preventing further air raids. ${ }^{73}$ This was, in fact, the IAPF's 'strongest weapon': against undefended aerodromes, it would be almost certainly and immediately decisive in disarming the aggressor. ${ }^{74}$

Noel Baker's plan recognized the potential risk from civilian aircraft pressed into use as 
bombers in wartime. Groves had drawn attention to this danger in 1922, noting that Britain's airlines were few and weak when compared with their Continental rivals. ${ }^{75}$ This meant that if national air forces were internationalized or even completely disbanded, a knock-out blow could still be carried out by these makeshift bombers. ${ }^{76}$ Hence, by the 1930s the internationalisation of military aviation was almost always linked to the internationalisation of civil aviation. One scheme which received some attention was authored by a committee of which Jonathan Griffin, editor of Essential News, was the secretary. As summarized in his 1935 book, Britain's Air Policy, the committee envisaged the creation of an International Directorate of Aviation (IDA), composed of the transport ministers of those nations party to the World Disarmament Conference. IDA would administer a corporation, World Airways, with 'exclusive ownership of all present and future aircraft and aerodromes, together with spare-parts and ground equipment'. ${ }^{77}$ The personnel of World Airways would be drawn from all over the world, with no more than 10 per cent from any one country. ${ }^{78}$ Stock would be sold to the public through post offices, much like war bonds. Since World Airways would be prohibited from insuring its aircraft and aerodromes against war losses, it was hoped that this would mean that 'The man in the street would be financially interested in the prevention even of wars not involving his country directly, ${ }^{79}$ World Airways would itself monopolise the major air routes, but at IDA's discretion could authorize private companies to manage subsidiary routes. No subsidies would be paid by governments except to World Airways itself, however, in order to prevent the formation of any illicit connections between nation states and airlines. ${ }^{80}$ In a crisis, it could be withdrawn from any of the nations involved. In wartime, a two-thirds majority of the signatories to the Disarmament Conference, 
including the members of the League Council but excluding any countries at war, could 'order the use of the world's civil aviation for military sanctions against a country declared by them guilty of aggression' - in effect, an extemporized international air force ${ }^{81}$ According to Griffin, in order to prevent 'a catastrophe which would destroy civilisation', the only alternatives were 'either international ownership of civil aviation, or a powerful international air force' ${ }^{82}$ Indeed, the more internationalised civil aviation became, the more secure it would be, and the less need for internationalised military aviation; and vice versa. ${ }^{83}$ But it was more usual for both concepts to be advocated in parallel, with the international air force as insurance against the subversion of internationalised civil aviation by a rogue state.

\section{A Believers and sceptics}

Some of the competing plans for an international air force were just as detailed as Noel Baker's. Others were mere sketches, such as that given in 1934 by Clement Attlee, then deputy leader of the Labour Party. ${ }^{84}$ Some of the differences were trivial: Charlton chose the French colony Tunis for its main base, as it was within bomber range of most potential aggressors, while the New Commonwealth settled on the easily-defensible British mandate of Palestine. ${ }^{85}$ A more important question was which potential enemies should be defended against. Rogue members of the League itself would presumably be disarmed, or nearly so, and could be dealt with by a relatively small, lightly armed force. But by 1937, it was clear that neither Germany nor Italy would join an international air 
force. Charlton therefore proposed that a superiority in strength of one third over the largest national air force still in existence would be required, meaning some 3000 aircraft in total. ${ }^{86}$ Attlee thought that the role of air control could be internationalised as well, making the international air force responsible for 'preserving order in unquiet areas on the borders of civilisation', as the RAF was already doing in Iraq and Waziristan ${ }^{87}$ Some writers, such as Squadron Leader R.E.G. Fulljames, favoured an air force formed from separate contingents from each nation, since this minimised the infringement of sovereignty and so seemed politically feasible. ${ }^{88}$ But most agreed with Charlton, who insisted that the only way to foster a truly international spirit was with units composed of men from all nationalities. ${ }^{89}$

Most serious of all was the disagreement over precisely how an international air force was to be used. Philip Mumford noted the existence of two schools of thought. One proposed 'an Interceptor Force, i.e. a force that must confine its activities to interception or prevention of any air raids that might be attempted by the misuse of civil aviation', such as Noel Baker advocated, and the other 'wished the Air Police to be for general support and protection of the Covenant of the League of Nations', that is for counterattacks as well as air defence. ${ }^{90}$ Mumford himself favoured the latter, since an interceptor force would inevitably be drawn into attacks on military targets anyway. ${ }^{91}$ But even so, he ruled out the use of an international air force against civilians, based on 'considerations of humanity ${ }^{92}$ By contrast, Charlton did not believe that the bomber should necessarily be restrained in defence of collective security. In a fictional coda to The Menace of the Clouds he described how an 'International Strategic Reserve' might 
respond to an Italian attack on Egypt, by bombing Italy's ports and dams, leading to civilian panic and an end to the war. This knock-out blow ultimately resulted in 'a reign of universal peace'. ${ }^{93}$ Mumford and Charlton were both former RAF officers who had served in both the First World War and postwar Iraq. As such, they perhaps held a more realistic attitude to the uses of airpower than moderate pacifists like Noel Baker and Griffin.

There were potential constitutional difficulties. J.M. Spaight, a jurist and Air Ministry civil servant, believed that no nation would be willing to grant the League the power to decide questions of war and peace, and offered as evidence the successive failures of the Treaty of Mutual Assistance and the Geneva Protocol. ${ }^{94}$ His argument was that the Covenant, when supplemented by regional agreements of the Locarno type, was already adequate for the organization of collective security. In wartime, this would necessarily involve the heavy use of aircraft to stop any aggression and so, in practice, would be internationalised airpower:

You organise international air power indirectly to-day when you organise a system of mutual guarantee and assistance. The fact is significant. One can conceive a system of extended pacts of the Locarno type leading in time, first, to the indirect, eventually, perhaps, to the direct organising of international air power on a world-wide basis. $^{95}$

Davies believed that the Covenant already revoked from nations the 'so-called right to go 
to war except under certain conditions', and so no additional rights would be yielded through the organization of international airpower. ${ }^{96}$ But conservatives were not convinced, preferring to create a strong Britain in splendid isolation. In 1923, the rightwing military intellectual J.F.C. Fuller was extremely sceptical of internationalised force, arguing in highly gendered terms that 'The nation which depends for the security of its honour on some international police force has become but a kept-woman among nations'. ${ }^{97}$ Harold Balfour, a Conservative MP, similarly posited, in regard to the internationalisation of civil aviation, that 'we cannot afford to surrender our own right to develop on our own lines for our particular requirements', particularly given the increasing importance of civil aviation in peace and war. ${ }^{98}$

The problem of sovereignty led to the even more vexed question of a superstate. For the sceptical Spaight, following the former Labour air minister Lord Thomson, before an international air force could be created 'the League must become a super-State; in other words, the institution of such a force must follow, not precede, the federation of (at any rate) Europe'. ${ }^{99}$ Griffin noted that many of his fellow citizens feared 'the nebulous nightmare of a world authoritarian State' because of the potential for universal bureaucratic interference in everyday life, but denied that the organization required for this could ever be achieved in practice. ${ }^{100}$ Yet others welcomed the prospect of a superstate. Lord Allenby, one of Britain's great generals, asked in 1936 whether

Is it too much to believe that the human intellect is equal to the problem of designing a world state wherein neighbours can live without molestation; in 
collective security? It does not matter what the state is called; give it any name you please:- League of Nations; Federated Nations; United States of the World. Why should there not be a world police; just as each nation has a national police force ${ }^{101}$

Bertrand Russell, a pacifist as well as an eminent philosopher, believed that 'permanent peace' could only be achieved by 'a single supreme world government, possessed of irresistible force', with 'air warfare [its] exclusive prerogative'. All military and civilian aircraft would be owned by the world state. ${ }^{102}$ In his novel The Shape of Things to Come, Wells foresaw that after the next, catastrophic war, airmen would begin to knit a shattered civilisation back together under the auspices of Air and Sea Control, a Kiplingesque organization controlling international transport. Air and Sea Control later transforms into a benevolent but authoritarian Air Dictatorship which uses its monopoly of airpower to control the world. ${ }^{103}$ This was simply a variation of Wells' ideal of a technocratic utopia which he advanced at several points throughout his life - The World Set Free being another example - and one which was later popularized in the spectacular 1936 film, Things to Come, one of the best-known popular depictions of a world state. ${ }^{104}$

Some on the left were also skeptical. Absolute pacifists like Helena Swanwick argued bluntly that, since a knock-out blow would probably be launched without warning, 'All the International Force could do, perhaps, if not too late to do anything, would be to devastate the aggressor country and its inhabitants' ${ }^{105}$ Swanwick, the former head of the British section of the Women's International League for Peace and Freedom, totally 
opposed the use of force in international relations on moral grounds:

When I hear a mild-mannered pacifist speak of air-bombardment as the 'technical means of enforcing a unanimous decision', I marvel that any man can within the space of one generation so utterly forget the horror that lies under such complacent language. ${ }^{106}$

But she also believed that an international air force would itself endanger peace: the threat of military sanctions might actually encourage an aggressor to anticipate an adverse ruling by the League and attack first. ${ }^{107}$ The communist journalist Tom Wintringham also rejected the international air force concept, but for very different reasons. He viewed it as a distraction to the left: war was inevitable and presented the working classes with their best chance for revolution. Indeed, they had no need to fear aircraft as it was they who made and maintained them. ${ }^{108}$ Wintringham also criticized the assumption that an international police force would necessarily be benevolent: this was a 'slightly ludicrous suburbanism. It is a view of the police natural to Hampstead Garden Suburb' - and not to the working classes, who had a very different perspective on police violence. ${ }^{109}$ H.N. Brailsford, a veteran left-wing journalist, was in favour of an international police force in principle, but only after nationalism had been discarded and a world federation of socialist states formed: 'one would not propose to endow the League of Nations, as it exists to-day, with an international force', since it would be used 'to create a stifling international despotism'. ${ }^{110}$ As popular as the internationalisation of aviation was on the left, due to disparate attitudes towards the legitimacy of violence it 
never quite became a universally-desired goal.

A Decline and revival

As the 1930s waned, the possibility of an international air force seemed ever more remote. The League had failed to operate effectively in crisis after crisis, which underscored the need for a reform of the international order, but the increasingly obvious discord between democracies and dictatorships made this a futile hope. In 1937 Aldous Huxley, in An Encyclopadia of Pacifism, mocked the very idea of international cooperation: 'In the world of to-day it is inconceivable that French and Germans, Russians and Italians, Americans and Japanese would unite together in order to man such a force'. ${ }^{111}$ Even Charlton, always one of the most strident advocates of an international air force, became pessimistic. In his contribution to The Air Defence of Britain, published shortly after the Munich Conference, he still hoped that eventually 'the supra-national air force would stand alone as the policeman of the world'. But he admitted that such a force might take as long as 'five or seven years to reach a necessary pitch of efficiency'. There was no longer enough time to educate British and international opinion on the need for internationalism in the air, and so Charlton was forced to reverse his earlier opposition to counter-bombing. 'There is no escape from the immediate necessity to rearm', Charlton wrote. In fact, it should be sped up. ${ }^{112}$

The situation did not improve in the early years of the Second World War. The potential reconstruction of the international order would have to wait until victory had been won; 
short- and medium-term responses to the danger of bombing, such as air defence, counter-bombing and air raid precautions, clearly took priority. Wells was, characteristically, one of the few looking further ahead. He published a number of books and pamphlets alluding to the need for a new world order. In The Common Sense of War and Peace, published in mid-1940 before the start of the Blitz, he bluntly predicted that 'Either man will put an end to air war or air war will put an end to mankind'. The only solution, Wells contended, was 'to take at least the control of the air out of the scheme of national and imperial politics and entrust it to a fully-empowered world-directorate', a limited world federation very much in keeping with the Air and Sea Control of The Shape of Things to Come. ${ }^{113}$ But even those sympathetic to the internationalisaton of aviation dismissed the idea as impractical. George Orwell criticized Wells' technocratic utopianism as more appropriate to the 1900s than the 1940s. Even though he admitted that 'All sensible men for decades past' largely agreed with Wells, he asked:

What is the use of saying that we need federal world control of the air? The whole question is how we are to get it. What is the use of pointing out that a World State is desirable? What matters is that not one of the five great military powers would think of submitting to such a thing. ${ }^{114}$

Writing during the Blitz, aviation historian Bernard Davy favoured a Fabian solution of allowing international control to develop gradually 'through the evolution of society and of human conduct, which it is hoped may be accelerated after the Second World War'. ${ }^{115}$ Others rejected altogether any idea of reviving collective security after the war, such as 
the anonymous Auspex, who trusted instead in 'the mighty navies and air fleets which we and the United States will have at our disposal at the end of the war'. Anglo-American power would protect nations of 'good will' in this 'Freedom Area'. ${ }^{116}$ As the free world contracted, the allure of internationalism faded, instead to be replaced by the hope of a partnership between English-speaking peoples. ${ }^{117}$

In 1944 and 1945, the impending victory of the Allied coalition - the 'United Nations' along with the self-evidently crucial importance of aircraft revived interest in a future international order shaped and protected by airpower. The young man who expressed to Lord Dunglass his belief that postwar security problems would 'be looked after for us by an international Air Force' was not alone. ${ }^{118}$ Spaight, now retired from his post as assistant principal secretary at the Air Ministry, had been sceptical of the possibility of an international air force fifteen years earlier. But he now forthrightly asserted that the bomber was the 'ideal weapon for smothering aggression' with an 'almost limitless capacity as a war-breaker'. He hoped that the present alliance would not disarm after the war but would instead serve as the basis for a 'new international society'. ${ }^{119}$ But while the war had demonstrated the value of airpower, it showed even more clearly that aircraft alone could not bring victory, as Groves and others had predicted before 1939. Hence the insistence of even those who had devoted their careers to the air on the need for a combined-arms approach. For example, Air Vice-Marshal Donald Bennett's detailed proposal, published early in 1945, for an 'International Law Force' did not place any special emphasis on airpower, despite his having commanded Bomber Command's elite pathfinder squadrons. ${ }^{120}$ However, the appearance of V-weapons and then atomic bombs, 
while leading to doubts about the ability of an international air force to prevent war without unacceptable levels of destruction, also resurrected the spectre of the knock-out blow. ${ }^{121}$ When Chapter VII of the United Nations Charter was finalized at the San Francisco Conference in 1945, it listed airpower first among the military options placed at the Security Council's disposal in order to respond to acts of aggression, and not by accident. ${ }^{122}$ For the first time, then, an international air force became a real possibility only to fall victim to Cold War politics within a few short years. ${ }^{123}$

\section{A Conclusion}

The internationalist response to the threat of the knock-out blow had deep roots in 19th century liberalism and the attempt to create a world order based on the rule of law, not of force. ${ }^{124}$ But the First World War amply showed the shortcomings of the existing system of relations between the world's powers. An arms race on land and sea had contributed to the tensions preceding the outbreak of war, and barbarism seemed to mark its conduct far more than humanity. ${ }^{125}$ The instinctive liberal response was to call for further limitations on the conduct of war and for multilateral disarmament. But there also arose a new idea, or at least one which had previously been no more than a utopian dream: collective security. Even more so than disarmament and limitation, collective security became an orthodoxy in interwar Britain. Large majorities of the public supported it, and so, unsurprisingly, did all the major political parties. ${ }^{126}$

The coming of airpower complicated all of these hopes. The possible convertibility of 
civilian aircraft to military use meant that the abolition of military aircraft alone was not enough to guarantee security. The theory of the knock-out blow, if true, meant that attacking civilians was the surest and the quickest way to win a war, a temptation to any nation whatever international law might say. In the air age, the workings of diplomacy appeared to be far too slow to have any prospect of stopping a knock-out blow before it devastated its victim. And since it did not allow for the terrible power of the bomber, the League of Nations and its Covenant, in many ways a radical experiment, appeared dangerously out of date from the moment of its creation.

Attempts were made to constrain airpower. Disarmament talks considered not only military aircraft, but also civilian aircraft. ${ }^{127}$ Jurists and diplomats attempted to come up with ways to regulate the conduct of aerial warfare. ${ }^{128}$ So-called 'air Locarnos' were discussed as a way to furnish collective security with a meaningful response to air attack. ${ }^{129}$ But the most ambitious idea for achieving this end was the international air force, an attempted compromise between liberal ideals and military necessity. It promised a way not just to win wars, but to prevent them altogether. The best way to prevent airpower from destroying civilization, in this view, was to co-opt it in defence of the international order. The perceived necessity of such a course varied with the plausibility of the threat posed by the knock-out blow; its practicality varied with the strength of internationalism and the willingness of nations to cede some of their sovereignty to a supranational organization.

The true significance of the international air force is that it forced even those who were 
not naturally internationalists by inclination to view a loss of national sovereignty as less of an evil than aerial devastation. Internationalism in interwar Britain was therefore stronger than its intellectual links with the failing Liberals might suggest: it had the potential to unite right, left and centre against the spectre of a knock-out blow. But the case of the international air force also illustrates the weaknesses of a pragmatic approach to international affairs. As an attempt to create a consensus among peace-minded intellectuals that force could legitimately be used to defend the status quo, the proposed internationalisation of aviation merely alienated absolute pacifists on the left of the peace movement. Even proponents of an international air force could not agree amongst themselves whether it should be purely defensive in nature or whether it needed to be able to call on the terrible power of the bomber to be effective. On the right, committed nationalists doubted that an air force controlled by international committee could ever be robust enough to maintain the peace, and remained convinced that it was necessary for Britain to possess sufficient armed forces for any eventuality. So while the international air force may have been more successful than any other internationalist ideal in uniting the political extremes in interwar Britain, it still failed to win a consensus of opinion, because it ultimately could not resolve fundamental differences of opinion on both pragmatic and moral matters. But that it never actually existed is no measure of the hopes - and fears - that the international air force aroused among the generations scarred by the experience of world war. 
${ }^{1}$ HC Deb, 10 November 1932, vol. 270, cols. 525, 632. On the drafting of Baldwin's speech, see K. Middlemas and J. Barnes, Baldwin: A Biography (London, Weidenfeld and Nicolson, 1969), pp. 735-6; S. Roskill, Hankey: Man of Secrets (London, Collins, 1974), III, pp. 62-4.

${ }^{2}$ See B.D. Powers, Strategy Without Slide-Rule: British Air Strategy 1914-1939 (London, Croom Helm, 1976); U. Bialer, The Shadow of the Bomber: The Fear of Air Attack and British Politics, 1932-1939 (London, Royal Historical Society, 1980).

${ }^{3}$ See T.B. Davis, Rhetoric and Reality in Strategic Air Warfare: The Evolution and Reality of British and American Ideas about Strategic Bombing, 1914-1945 (Princeton and Oxford, Princeton University Press, 2002), chapter 2.

${ }^{4}$ E.g., P.R.C. Groves, Behind the Smoke Screen (London, Faber and Faber, 1934), p. 42. On Groves, see R. Higham, The Military Intellectuals in Britain: 1918-1939 (Westport, Greenwood Press, 1966), pp. 170-6.

${ }^{5}$ E.g., see P.J. Noel Baker, Disarmament (London, Hogarth Press, n.d. [1927]).

${ }^{6}$ On British internationalism, see C. Sylvest, 'Continuity and change in British liberal internationalism, c. 1900-1930’, Review of International Studies XXXI (2005), pp. 26383.

${ }^{7}$ On early European federalism, see C.H. Pegg, Evolution of the European Idea, 19141932 (Chapel Hill and London, University of North Carolina Press, 1983).

${ }^{8}$ The more general term was 'international police force', encompassing military, naval and aerial forces, but the international air force received by far the most attention.

${ }^{9}$ See R. Overy, The Morbid Age: Britain Between the Wars (London, Allen Lane, 2009), especially chapter 6 .

${ }^{10}$ On the international air force concept generally, see R. Beaumont, Right Backed by Might: The International Air Force Concept (Westport and London, Praeger, 2001); S.W.H. Zaidi, 'Technology and the Reconstruction of International Relations: Liberal Internationalist Proposals for the Internationalisation of Aviation and the International Control of Atomic Energy in Britain, USA and France, 1920-1950', Ph.D. thesis (University of London, 2008), chapters 2 and 3. Zaidi argues that the various international air force proposals were not so much reactions to the threat of the knock-out blow, as argued here, as they were attempts 'to use aviation to reconstruct international relations'. Op. cit., p. 11. See also D. Edgerton, Warfare State: Britain, 1920-1970 (Cambridge, Cambridge University Press, 2006), pp. 83-4, 314.

${ }^{11}$ See J.M. Spaight, An International Air Force (London, Gale \& Polden, n.d. [1932]), pp. 29-31; also Beaumont, Right, pp. 1-11.

12 J.L.J. Carter, Peggy the Aeronaut (London, Everett \& Co., 1910), p. 117. See also Michael Paris, Winged Warfare: The Literature and Theory of Aerial Warfare in Britain, 1859-1917 (Manchester and New York, Manchester University Press, 1992), p. 45.

${ }^{13}$ Rudyard Kipling, “"As easy as A.B.C.” A tale of 2150 A.D.', London Magazine (April 1912), p. 164.

${ }^{14}$ Much of the impetus for an international police force came from the League to Enforce Peace, founded in the United States in 1915: see Beaumont, Right, 12-3. But similar suggestions were made in Britain: see, e.g., L.S. Woolf, International Government: Two 
Reports (London, Fabian Society and George Allen \& Unwin, 1916), pp. 253-7.

${ }^{15}$ See John H. Morrow, Jr., The Great War in the Air: Military Aviation from 1909 to 1921 (Washington and London, Smithsonian Institution Press, 1993).

${ }^{16}$ Claude Grahame-White and Harry Harper, 'Two years of aerial war', Fortnightly Review C (August 1916), pp. 195-210; P.R.C. Groves, Our Future in the Air: A Survey of the Vital Question of British Air Power (London, Hutchinson \& Co., 1922).

${ }^{17}$ P.R.C. Groves, 'Our future in the air', The Times, 21 March 1922, pp. 13-4.

${ }^{18}$ See Powers, Strategy, pp. 129-31.

${ }^{19}$ On the Inter-Allied Independent Force, see E. Ash, Sir Frederick Sykes and the Air Revolution, 1912-1918 (London and Portland, Frank Cass, 1999), pp. 159-62.

${ }^{20}$ See, e.g., the official and unofficial proposals from various nations summarised in Davies, The Problem of the Twentieth Century: A Study in International Relationships (London, Ernest Benn, 1930), pp. 726-35.

${ }^{21}$ See D. Carlton, 'The problem of civil aviation in British air disarmament policy, 19191934', Journal of the Royal United Service Institution CXI (1966), p. 309.

${ }^{22}$ Robert Cecil to Jan Smuts, 6 October 1922; quoted in Carlton, 'Civil aviation', p. 309.

${ }^{23}$ P.R.C. Groves, 'Air power and disarmament', The Times, 18 September 1922, p. 11.

${ }^{24}$ Groves, Smoke Screen, pp. 314-5. Groves had been peripherally involved with the Inter-Allied Independent Force in 1918, and in 1919 had attempted to preserve it as a tool to coerce a recalcitrant Germany: P.R.C. Groves to H.M. Trenchard, 4 December 1919, 3(c), Groves papers, Liddell Hart Centre for Military Archives, Kings College London (KCL).

${ }^{25}$ See Z. Steiner, The Lights that Failed: European International History 1919-1933 (Oxford, Oxford University Press, 2005), pp. 379-82.

${ }^{26}$ Winston S. Churchill, The World Crisis: The Aftermath (London, Thornton Butterworth, 1929), p. 27.

${ }^{27}$ Noel Baker, Disarmament, p. 242. Noel Baker did not hyphenate his name until the late 1930s.

${ }^{28}$ See J. Bourke, Fear: A Cultural History (London, Virago, 2005), pp. 65-7.

${ }^{29}$ William McDougall, Janus: The Conquest of War (London, Kegan Paul, Trench, Trubner \& Co., n.d. [1927]), pp. 126-7.

${ }^{30}$ Op. cit., pp. 131.

${ }^{31}$ See M.C. Pugh, 'An international police force: Lord Davies and the British debate in the 1930s', International Relations IX (1988), pp. 335-51; M. Pugh, 'Policing the world: Lord Davies and the quest for order in the 1930s', International Relations XVI (2002), pp. 97-115.

${ }^{32}$ Davies, Twentieth Century.

${ }^{33}$ See D.S. Birn, The League of Nations Union 1918-1945 (Oxford, Clarendon Press, 1981), pp. 117-8; M. Ceadel, Semi-Detached Idealists: The British Peace Movement and International Relations, 1854-1945 (Oxford, Oxford University Press, 2000), 283-4.

${ }^{34}$ Davies, Twentieth Century, pp. 367-8.

${ }^{35}$ An International Air Force: Its Functions and Organisation (London, The New Commonwealth, 1934).

${ }^{36}$ Davies, Force and the Future (London, The New Commonwealth, 1934), p. 9.

${ }^{37}$ Davies, Twentieth Century, pp. 361-3. 
${ }^{38}$ Op. cit., p. 363.

${ }^{39}$ Op. cit., pp. 363-4.

${ }^{40}$ Op. cit., pp. 364-6.

${ }^{41}$ Op. cit., pp. 367-8.

${ }^{42}$ See Philip S. Mumford, Humanity, Air Power and War: An Essay upon International Relations (London, Jarrolds, 1936), chapter 8; also Beaumont, Right, pp. 46-9. Not that the French proposals were particularly sincere: see Zaidi, 'Technology', p. 62.

${ }^{43}$ H.G. Wells, The Shape of Things to Come: The Ultimate Revolution (London, Hutchinson \& Co., 1933); Michael Arlen, Man's Mortality: A Story (London, William Heinemann, 1933); Brian Tunstall, Eagles Restrained (London, George Allen \& Unwin, 1936).

${ }^{44}$ Norman Angell, The Menace to Our National Defence (London, Hamish Hamilton, 1934); Philip Noel Baker, 'The International Air Police Force', in Challenge to Death (London, Constable \& Co., 1934), pp. 206-39.

${ }^{45}$ The Liberal Way: A Survey of Liberal Policy, Published by the Authority of the National Liberal Federation (London, George Allen \& Unwin, 1934), p. 41. See Beaumont, Right Backed by Might, p. 49; R.S. Grayson, Liberals, International Relations and Appeasement: The Liberal Party, 1919-1939 (London and Portland, Frank Cass, 2001), pp. 90, 95

${ }^{46}$ The Next Five Years: An Essay in Political Agreement (London, Macmillan and Co., 1935), p. 296. The Next Five Years Group comprised well over a hundred members, including Angell, Cecil, Wells and Jonathan Griffin. On its Liberal makeup, see M. Freeden, Liberalism Divided: A Study in British Political Thought 1914-1939 (Oxford, Clarendon Press, 1986), pp. 360-3.

${ }^{47}$ In I. Dale, ed., Labour Party General Election Manifestos, 1900-1997 (London, Routledge, 2000), p. 46.

${ }^{48}$ Jonathan Griffin, Britain's Air Policy: Present and Future (London, Victor Gollancz, 1935), p. 183.

${ }^{49}$ G.D.H. Cole, The People's Front (London, Victor Gollancz Ltd, 1937), p. 172.

${ }^{50}$ On Charlton's socialism, see L.E.O. Charlton, More Charlton (London, New York and Toronto, Longman, Green and Co., 1940), pp. 156-7, 163.

${ }^{51}$ During the Spanish Civil War, Groves toured the Nationalist areas, which he viewed as the front line against Soviet influence: P.R.C. Groves, 'This air business', unpublished ms. (c. 1939), 5(e), Groves papers, KCL.

${ }^{52}$ See Birn, League of Nations Union, p. 171.

${ }^{53}$ See, e.g., 'Great Britain and the air', Spectator, 27 July 1934, p. 120.

${ }^{54}$ See Mumford, Humanity, pp. 168-79.

${ }^{55}$ See Beaumont, Right, p. 49.

${ }^{56}$ For example, it was summarised in Griffin, Air Policy, pp. 106-17.

${ }^{57}$ Noel Baker, 'Police Force', p. 214. The acronym is due to the author, not Noel Baker. On Challenge to Death, an important collective attempt by British intellectuals to articulate a case against war, see Overy, Morbid Age, pp. 219-24.

${ }_{58}^{58}$ Noel Baker, 'Police Force', p. 215.

${ }^{59}$ Op. cit., p. 216.

${ }^{60}$ Op. cit., p. 218. 
${ }^{61}$ Op. cit., p. 219.

${ }^{62}$ Op. cit., p. 220

${ }^{63}$ Op. cit., p. 221.

${ }^{64}$ Op. cit., p. 222.

${ }^{65}$ Op. cit., pp. 223-4.

${ }^{66}$ Op. cit., p. 226.

${ }^{67}$ Op. cit., pp. 229-30.

${ }^{68}$ Op. cit., p. 230.

${ }^{69}$ Op. cit., p. 231; emphasis in original.

${ }^{70}$ Philip Noel Baker, 'A national air force no defence', in Challenge to Death (London, Constable \& Co., 1934), pp. 196-203.

${ }^{71}$ Noel Baker, 'Police Force', pp. 234-5.

${ }^{72}$ Op. cit., p. 231; emphasis in original.

${ }^{73}$ Op. cit., pp. 231-2.

${ }^{74}$ Op. cit., p. 236.

${ }^{75}$ For example, P.R.C. Groves, 'Our future in the air', The Times, 1 July 1922, p. 15.

${ }^{76}$ See Carlton, 'Civil aviation'.

${ }^{77}$ Griffin, Air Policy, p. 31.

${ }^{78}$ Op. cit., p. 32.

${ }^{79}$ Op. cit., p. 33.

${ }^{80}$ Op. cit., pp. 34-5.

${ }^{81}$ Op. cit., p. 36.

${ }^{82}$ Op. cit., p. 29.

${ }^{83}$ Op. cit., p. 103.

${ }^{84}$ C.R. Attlee, An International Police Force (London, The New Commonwealth, 1934).

${ }^{85}$ L.E.O. Charlton, The Menace of the Clouds (London, Edinburgh and Glasgow, William Hodge \& Company, 1937), pp. 258-60; International Air Force, pp. 54-5.

${ }^{86}$ Charlton, Menace, p. 269.

${ }^{87}$ Attlee, Police Force, p. 7. On air control, see D.E. Omissi, Air Power and Colonial Control: The Royal Air Force 1919-1939 (Manchester and New York, Manchester University Press, 1990); P. Satia, 'The defense of inhumanity: air control and the British idea of Arabia', American Historical Review CXI (2006), pp. 16-51.

${ }^{88}$ R.E.G. Fulljames, 'An international air police force', Royal Air Force Quarterly VI (July 1935), p. 246.

${ }^{89}$ Charlton, Menace, pp. 278-9.

${ }^{90}$ Mumford, Humanity, p. 176.

${ }^{91}$ Op. cit., p. 178.

${ }_{92}$ Op. cit., p. 179.

${ }^{93}$ Charlton, Menace, p. 286.

${ }^{94}$ Spaight, Air Force, pp. 59-63.

${ }^{95}$ Op. cit., p. 65; emphasis in original.

${ }^{96}$ Davies, Force, p. 43.

${ }^{97}$ J.F.C. Fuller, The Reformation of War (London, Hutchinson \& Co., 1923), p. 282.

${ }^{98}$ Harold Balfour, 'The problem of air defence', in Nigel Tangye, ed., The Air is Our Concern: A Critical Study of England's Future in Aviation (London, Methuen and 
Company, 1935), p. 155.

${ }^{99}$ J.M. Spaight, Pseudo-Security (London, New York and Toronto, Longmans, Green \& Co., 1928), p. 111.

${ }^{100}$ Griffin, Air Policy, p. 129.

${ }^{101}$ Allenby, Allenby's Last Message: World Police for World Peace (London, The New Commonwealth, 1936), p. 9.

${ }^{102}$ Bertrand Russell, Which Way to Peace? (London, Michael Joseph, 1936), p. 173.

${ }^{103}$ Wells, Shape of Things to Come.

${ }^{104}$ H.G. Wells, The World Set Free: A Story of Mankind (London, Macmillan and Co., 1914). See P. Coupland, 'H. G. Wells's "liberal fascism”", Journal of Contemporary History XXXV (2000), pp. 541-58; D. Edgerton, England and the Aeroplane: An Essay on a Militant and Technological Nation (Basingstoke and London, Macmillan Academic and Professional, 1991), pp. 44-5; C. Frayling, Things to Come (London, BFI Publishing, 1995).

${ }^{105}$ H.M. Swanwick, New Wars for Old (London, Women's International League, 1934), p. 28.

${ }^{106}$ Op. cit., p. 43.

${ }^{107}$ Op. cit., p. 29.

${ }^{108}$ T.H. Wintringham, The Coming World War (London, Wishart Books, 1935), p. 231. Wintringham himself had been an engine fitter in the RFC during the First World War. See D. Fernbach, 'Tom Wintringham and socialist defense strategy', History Workshop Journal XIV (1982), p. 64.

${ }^{109}$ Wintringham, World War, p. 173.

${ }^{110}$ Henry Noel Brailsford, Property or Peace (London, Victor Gollancz, 1934), pp. 171$3,299$.

${ }^{111}$ Aldous Huxley, An Encyclopcedia of Pacifism (London, Chatto \& Windus, 1937), p. 60.

${ }^{112}$ L.E.O. Charlton, G.T. Garratt and R. Fletcher, The Air Defence of Britain (Harmondsworth, Penguin, 1938), p. 109.

${ }^{113}$ H.G. Wells, The Common Sense of War and Peace: World Revolution or War Unending (Harmondsworth, Penguin Books, 1940), p. 71. See also H.G. Wells, Guide to the New World: A Handbook of Constructive World Revolution (London, Victor Gollancz, 1941), p. 31.

${ }^{114}$ George Orwell, 'Wells, Hitler and the World State', Horizon: A Review of Literature and Art IV (August 1941), p. 134.

${ }^{115}$ M.J. Bernard Davy, Air Power and Civilization (London, George Allen \& Unwin, 1941), Civilization, p. 194.

${ }_{116}^{116}$ Auspex, Victory from the Air (London, Geoffrey Bles, 1941), p. 233.

${ }^{117}$ For a similar proposal, see Stephen King-Hall, Total Victory (London, Faber and Faber, 1941), pp. 214-22.

${ }^{118}$ HC Deb, 24 May 1944, vol. 400, col. 807.

119 J.M. Spaight, Bombing Vindicated (London, Geoffrey Bles, 1944), p. 156.

${ }^{120}$ Donald Bennett, Freedom from War (London, Pilot Press, 1945). See also Oliver Stewart, Air Power and the Expanding Community (London, George Newnes, 1944). 
${ }^{121}$ On the former point, see, for example, the Duke of Bedford, Total Disarmament or an International Police Force? (Glasgow, Strickland Press, 1944), p. 12.

${ }^{122}$ E. Grove, 'UN armed forces and the Military Staff Committee: a look back', International Security XVII (1993), pp. 173-4.

${ }^{123}$ Op. cit., pp. 180-1.

${ }^{124}$ M. Howard, War and the Liberal Conscience (London, Temple Smith, 1978).

${ }^{125}$ See D. Stevenson, Armaments and the Coming of War: Europe, 1904-1914 (Oxford, Clarendon Press, 1996); A. Kramer, Dynamic of Destruction: Culture and Mass Killing in the First World War (Oxford, Oxford University Press, 2007).

${ }^{126}$ Howard, Liberal Conscience, p. 86.

${ }^{127}$ See, for example, P.S. Meilinger, 'Clipping the bomber's wings: the Geneva Disarmament Conference and the Royal Air Force, 1932-1934', War in History VI (1999), pp. 306-30.

${ }^{128}$ For example, the draft Air Warfare Rules of 1923, reprinted in Thomson, Air Facts and Problems (London, John Murray, 1927), pp. 195-255.

${ }^{129}$ See Bialer, Shadow, chapter 3; M. Smith, British Air Strategy between the Wars (Oxford, Clarendon Press, 1984), pp. 148-51. 